\title{
APLIKASI PENCARIAN BENGKEL SEPEDA MOTOR MENGGUNAKAN LOCATION BASED SERVICE PADA WILAYAH KOTA TEBING TINGGI BERBASIS ANDORID
}

\author{
Janico Desmile, Mira Orisa, Febriana Santi Wahyuni \\ Program Studi Teknik Informatika S1, Fakultas Teknologi Industri \\ Institut Teknologi Nasional Malang, Jalan Raya Karanglo km 2 Malang, Indonesia \\ 1718113@scholar.itn.ac.id
}

\begin{abstract}
ABSTRAK
Pemilihan bengkel terdekat di Kota Tebing Tinggi merupakan permasalahan yang penting dikarenakan sepeda motor merupakan alat transportasi yang paling banyak digunakan masyarakat. Bahkan beberapa orang mengganggap sepeda motor menjadi kebutuhan primer dikarenakan sepeda motor dipakai untuk mencari penghasilan seperti ojek online, di samping banyak wisatawan atau masyarakat luar daerah yang mengunjungi Kota Tebing Tinggi dengan sepeda motor, baik milik pribadi maupun sewaan. Namum saat ini banyak bengkelbengkel kecil yang tidak diketahui oleh masyarakat luar daerah yang sedang melewati Kota Tebing Tinggi, karena Kota ini merupakan Kota transit sehingga membuat pengguna kesulitan dalam mencari informasi bengkel yang berada di Kota Tebing Tinggi. Penelitian ini merupakan solusi untuk menemukan bengkel terdekat di Kota Tebing Tinggi berbasis Aplikasi Android. Penelitian ini menggunakan metode Location Based Service dalam menemukan lokasi pengguna berada dan juga menggunakan Formula Haversine dalam hal mendapatkan informasi jarak dari lokasi pengguna ke tempat bengkel dalam satuan meter dan kilometer. Kebutuhan produk skripsi yang dikembangkan mencakup data bengkel yang berada di Kota Tebing Tinggi. Hasil penelitian ini adalah produk berupa aplikasi android, aplikasi ini bisa berjalan pada sistem operasi android 7 keatas. Berdasarkan hasil pengujian formula haversine dari 6 titik lokasi pengguna dengan membandingkan jarak yang disediakan Google Maps Api dengan hasil perhitungan rumus Haversine, aplikasi pencarian bengkel ini memiliki akurasi yang cukup baik dalam menentukan jarak bengkel terdekat.
\end{abstract}

Kata Kunci : Location Based Services, Sistem Informasi Geografi, Android, formula haversine

\section{PENDAHULUAN}

\subsection{Latar Belakang}

Menurut data yang diberikan oleh Biro Informasi dan Komunikasi Sumatera Utara, Kota Tebing Tinggi merupakan pusat kegiatan pintu gerbang Provinsi Sumatera Utara yang terletak di jalan raya timur dan tengah Sumatera. Hal tersebut meningkatkan Kota Tebing Tinggi sebagai kota transit. secara tidak langsung banyak warga luar kota seperti siantar dan medan yang melewati Kota Tebing Tinggi ini dengan menggunakan sepeda motor.

Kendaraan bermotor pada saat ini menjadi kebutuhan primer bagi sebagian rakyat Indonesia, khususnya di Kota Tebing Tinggi. Untuk saat ini hampir setiap orang memiliki kendaraan bermotor. kendaraan bermotor membutuhkan perawatan dan juga perbaikan jika mengalami [1].

Bengkel merupakan tempat di mana memperbaiki sepeda motor. Di kota Tebing Tinggi terdapat banyak bengkel yang tersebar di beberapa lokasi, baik bengkel besar maupun bengkel kecil. Karena kerusakan kendaraan motor bisa secara insidensial, maka masyarakan merasa sulit dalam hal mencari informasi bengkel yang berada di dekat mereka. Suatu sistem yang dapat membantu Masyarakat dalam mendapatkan informasi terkait daftar bengkel yang bisa didatangi dan memberikan informasi lengkap tentang bengkel tersebut dan memberikan fitur seperti sort berdasarkan nama, jarak fasilitas. Dapat juga mencari bengkel berdasarkan nama, kecamatan dan kelurahan [2].
Pada saat ini, Smartphone Android sangat berkembang pesat dan juga melekat dengan kehidupan masyarakat. Dengan adanya perkembangan android tersebut penulis menggagas pengembangan aplikasi dengan menggunakan Location Based Services untuk mencari keberadaan lokasi pengguna dan juga dengan menggunakan Formula Haversine untuk menentukan jarak dari lokasi pengguna ke lokasi tujuan berbasis android. Dengan aplikasi ini peneliti berharap dapat memberikan data yang valid tentang bengkel yang terletak di dalam Kota Tebing Tinggi, Sumatera Utara. Selain itu, aplikasi yang dikembangkan diharapkan dapat membantu pengguna sepeda motor dalam mendapatkan informasi yang dihasilkan seperti nama bengkel, alamat bengkel, lokasi bengkel di peta digital, nomor handphone pemilik beserta nama pemilik, hari kerja dan jam kerja, fasilitas yang berada dibengkel dan gambar-gambar bengkel. Aplikasi ini dilengkapi dengan pencarian berdasarkan nama bengkel kemudian penyortiran dari nama, jarak antara lokasi bengkel ke lokasi pengguna, dan fasilitas.

Berlandaskan masalah yang ada, maka penulis membuat aplikasi android yang bertujuan untuk memberikan informasi bengkel kepada pengguna. 


\subsection{Rumusan Masalah}

Rumusan masalah dari apliaski pencarian lokasi bengkel di Kota Tebing Tinggi dengan menerapkan location based service adalah sebagai berikut.

1. Bagaimana membangun Sistem Informasi Geografis berdasarkan data yang tersedia ?

2. Bagaimana menerapkan metode Location based service (LBS) untuk menentukan lokasi pengguna saat ini ?

3. Bagaimana menerapkan formula Haversine untuk menentukan jarak lokasi tujuan dari lokasi pengguna berada?

\subsection{Tujuan}

Tujuan dari pencarian lokasi bengkel di Kota

Tebing Tinggi dengan menerapkan location based service adalah sebagai berikut.

1. Membuat sebuah sistem yang dapat digunakan untuk mencari informasi bengkel yang berada di dalam Kota Tebing Tinggi

2. Menerapkan Location based service (LBS) untuk menentukan lokasi bengkel terdekat dengan pengguna

3. Menerapkan formula haversine untuk menentukan jarak lokasi tujuan dari lokasi pengguna berada

\section{TINJAUAN PUSTAKA}

\subsection{Penelitian Terdahulu}

Menurut Penelitian Nopriyanus yang berjudul "Aplikasi Pencarian Tempat Wisata Menggunakan Metode Location Based Service Pada Wilayah Kabupaten Timor Tengah Selatan Berbasis Android", dengan tujuan penelitian untuk merancang sistem yang menggunakan metode Location Based Service berbasis android yang mendukung teknologi GPS (Global Positioning System) dalam proses pembuatannya menggunakan metode location based service yang yang memiliki tujuan untuk membawa pengguna ke lokasi wisata yang sudah dituju oleh pengguna. Sehingga pengguna dapat mengetahui informasi yang berada di wisata tersebut [3].

Menurut Deti pada penelitiannya jang berjudul "Sistem Informasi Geografis Letak Lokasi Rumah Sakit Dan Apotek Kota Bengkulu Berbasis Android", dengan tujuan penelitian untuk merancang Sistem Informasi Geografis yang mempermudah pengguna dalam mencari lokasi rumah sakit dan apotek di kota bengkulu. Dan mempermudah pengguna dalam mengambil informasi rumah sakit dan apotek di kota bengkulu. Hasil penelitian yang dibentuk dalam bentuk aplikasi mobile dalam hal ini sangat memudahan orang dalam mencari informasi rumah sakit dan apotek [4].

Menurut Ichwan pada penelitiannya yang berjudul "Sistem Informasi Geografis Sebaran Pondok Pesantren Di Kota Malang" dengan tujuan penelitian membuat sebuah system informasi geografis berbasis web untuk mempermudah user dalam mencari data pesantren yang berada disekitarnya terkususnya didaerah malang dan juga mempermudah user dalam hal mencari informasi seputar pesantren. System ini dikembangkan menggunakan Arcgis. Aplikasi Sistem Informasi Geografis Kota Malang ini bisa dilihat bentuk Map, yang bertujuan untuk dapat mempermudah Departemen Agama dalam mendapatkan data pondok yang berada di kota Malang [5].

Menurut penelitian Yulianto dan rekan rekan yang berjudul "Penerapan Formula Haversine Pada Sistem Informasi Geografis Pencarian Jarak Terdekat Lokasi Lapangan Futsal". Penelitian ini mencari jarak lokasi pengguna menuju lokasi lapangan futsal menggunakan haversine. Hasil dari penelitian ini adalah sebuah aplikasi yang dapat memberikan informasi Lapangan futsat dan menentukan lokasi lapangan terdekat dari lokasi pengguna dengan membandingkan jarak antara lokasi lapangan futsal, dan mengambil jarak terkecil dari hasil haversine [7].

Menurut Erviana dan rekan rekannya pada penelitiannya yang berjudul "Analisa Algoritma Haversine Formula Untuk Pencarian Lokasi Terdekat Rumah Sakit Dan Puskesmas Provinsi Gorontalo". Penelitian ini memiliki hasil sebuah aplikasi yang dibuat menggunakan App Inventor, metode LBS (Location Based Service) untuk mendapatkan lokasi pengguna saat ini dan juga menggunakan Haversine dalam menghitung jarak kelokasi rumah sakit dari lokasi pengguna. Penelitian ini menyimpulkan bahwa jarak yang dihasilkan oleh haversine lebih kecil dari jarak sebenarnya, karena jarak yang dihasilkan oleh haversine adalah jarak yang didapat dari perhitungan melalui udara [8].

\subsection{Location Based Service (LBS)}

Location Based Service merupakan layanan berbasis lokasi. layanan berbasis lokasi adalah sebuah teknologi yang biasa digunakan dalam mengetahui lokasi perangkat yang digunakan. [6]

Dua elemen utama layanan berbasis lokasi adalah:

1. Pemetaan API

Menyediakan alat / sumber berdasarkan layanan lokasi, peta API menyediakan beberapa fungsi yang dapat digunakan untuk menampilkan, memanipulasi peta dan fungsi lainnya, seperti tampilan satelit, tampilan jalan atau tampilan gabungan. Paket dapat diakses melalui com. google.android.maps

\section{Location Providers (API Location)}

Sediakan teknologi pencarian lokasi yang digunakan oleh perangkat. API Lokasi memproses data GPS (Global Positioning System) dan data lokasi waktu nyata. Lokasi API terletak di paket android, yaitu di paket android.location. Dengan menggunakan Location Manager, pengguna dapat menentukan lokasi pengguna saat ini dengan mendeteksi perpindahan, melacak pergerakan / perpindahan dan kedekatan dengan lokasi tertentu. [6].

\subsection{Formula Haversine}

Rumus Haversine merupakan persamaan penting dalam sistem navigasi, dan rumus Haversine 
nantinya akan menghasilkan jarak terpendek antara dua titik, misalnya pada bola yang diperoleh dari bujur dan lintang. Formula ini pertama kali ditemukan oleh Jamez Andrew pada tahun 1805 dan pertama kali digunakan oleh Josef de Mendoza y Ríos pada tahun 1801. [8].

Istilah Haversine sendiri diciptakan oleh seorang profesor pada tahun 1835. James Inman. Josef de Mendoza y Ríos di Proc. Royal Soc, Pada 22 Desember 1796. Haversine digunakan untuk pertama kalinya dalam penelitian "Masalah Utama Astronomi Nautikal". Haversine digunakan untuk mencari jarak antar bintang [8].

Rumus Haversine adalah persamaan yang digunakan dalam navigasi, yang memberikan jarak sebuah lingkaran besar antara dua titik pada permukaan sebuah bola (bumi) berdasarkan bujur dan lintang. Rumus Haversine merupakan metode penentuan jarak antara dua titik dengan mempertimbangkan bahwa bumi bukanlah bidang datar melainkan bidang dengan derajat kelengkungan. Saat menggunakan rumus ini, diasumsikan bahwa efek ellipsoid diabaikan, yang merupakan akurat untuk sebagian besar perhitungan, dan ketinggian bukit dan kedalaman lembah di permukaan bumi diabaikan. [7].

Rumus Haversine merupakan persamaan penting dalam navigasi karena memberikan jarak lingkaran yang besar antara dua titik pada permukaan bola (bumi) berdasarkan bujur dan lintang dengan jari-jari R 6.367, dan dengan memahami bujur dan lintang pada peta [8].

Untuk mencari nilai Haversine dapat dihitung menggunakan persamaan rumus pada persamaan 1,2 , $3,4,5$

$\Delta$ lintang = lintang2- lingtang1

$\Delta$ bujur = bujur2- bujur 1

$\mathrm{a}=\sin ^{2}(\Delta$ lintang $/ 2)+\cos ($ lintang 1$) \cdot \cos ($ lintang 2$)$.

$\sin ^{2}(\Delta$ bujur/2)

$\mathrm{c}=2 \operatorname{atan} 2(\sqrt{a}, \sqrt{1-a})$

$\mathrm{d}=$ R.c

Dimana :

$\mathrm{R}=$ jari-jari bumi sebesar 6371e3(m)

$\Delta$ lintang $=$ besaran perubahan Lintang

$\Delta$ bujur $=$ besaran perubahan Bujur

$\mathrm{C}=$ titik potong sumbu

$\mathrm{d}=\operatorname{jarak}(\mathrm{m})$

\section{METODE PENELITIAN}

\subsection{Flowchart SIG}

Flowchart Pengerjaan dari aplikasi pencarian bengkel terdekat di kota tebing tinggi. Pertama merupakan bagian pencarian data dan pengumpulan data bengkel yang berada di tebing tinggi. Setelah selesai mengumpulkan data dilanjutkan dengan mendesign sitem yang akan dibuat, dari perancangan sitem sampai dengan perancangan prototipe aplikasi, Dilanjutkan dengan mengimplementasi hasil design
Setelah mengimplementasi dilanjutkan dengan uji coba aplikasi, trial dan eror, mencari bug pada aplikasi jika aplikasih sudah tidak ditemukan bug, maka dilanjutkan ke proses akhir dari aplikasi yaitu finalisasi, dilanjutkan dengan pembuatan buku laporan.

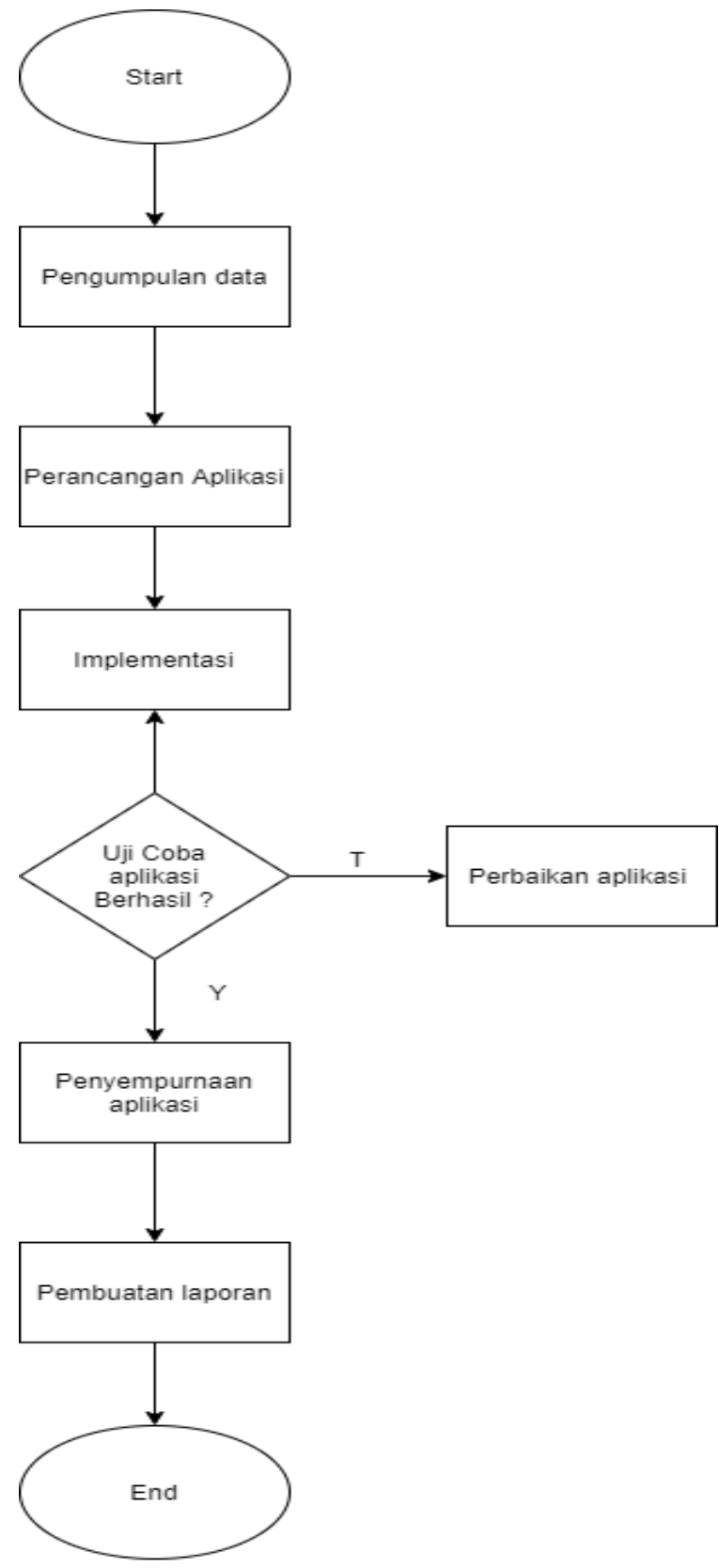

Gambar 1 Flowchar SIG

\subsection{Flowchart Sistem}

Flowchart ini menjabarkan bagaimana alur dari sistem. Berikut adalah rancangan untuk aplikasi atau sistem yang akan dikembangkan 


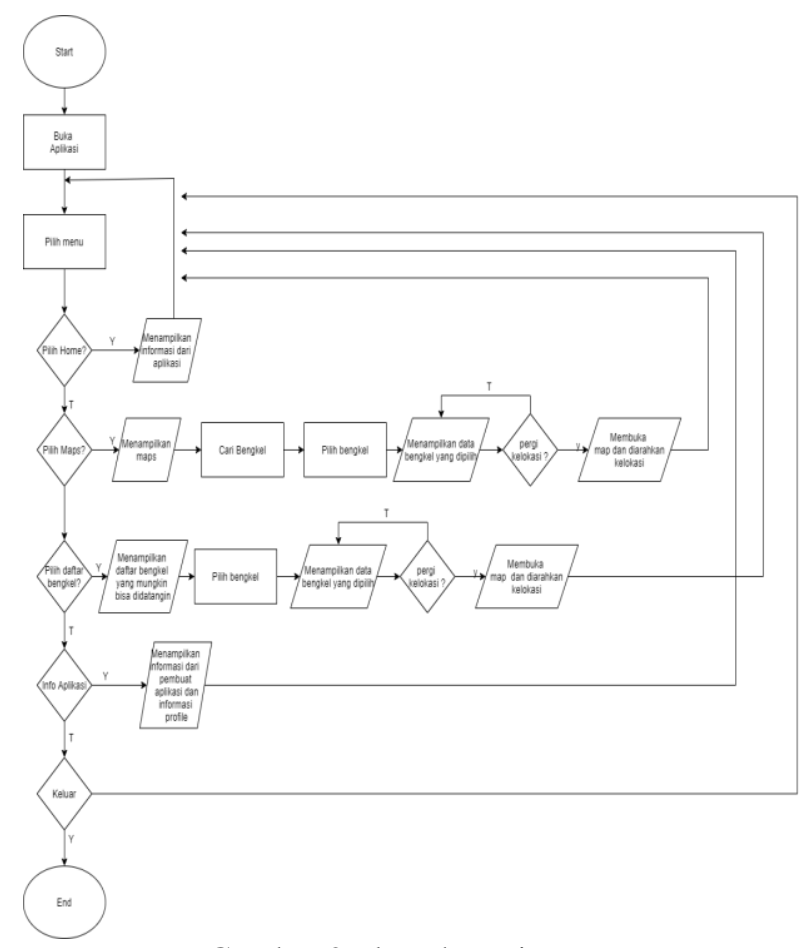

Gambar 2 Flowchart sistem

Berdasarkan flowchart Gambar 2, sistem ini dimulai ketika pengguna membuka aplikasi, Selanjutnya sistem menampilkan aplikasi dan menampilkan navigasi ,jika user menekan tombol map, jika iya maka system membuka map beserta dengan lokasi pengguna, dan user menekan tombol cari bengkel makan akan dilarikan ke halaman pilih bengkel, jika user memilih bengkel maka system mengembalikan data bengkel yang sudah diklik dan terdapat pilihan pergi kesana jika pergi maka system membuka map beserta rute menuju lokasi bengkel yang sudah di buka, Jika user menekan tombol daftar bengkel maka system mengembalikan daftar bengkel yang berada ditebing tinggi dan didalam halamannya terdapat proses pilih bengkel, jika user memilih bengkel maka system mengembalikan data bengkel yang sudah diklik dan terdapat pilihan pergi kesana jika pergi maka system membuka map beserta rute menuju lokasi bengkel yang sudah di buka, Jika user memilih tombol info Aplikasi maka system akan mengembalikan informasi dari pembuat aplikasi dan info dari aplikasi, Jika user menekan tombol keluar maka program akan langsung berakhir

\subsection{Struktur menu}

Berikut merupakan struktur menu di aplikasi pencarian bengkel terdekat di Kota Tebing Tinggi

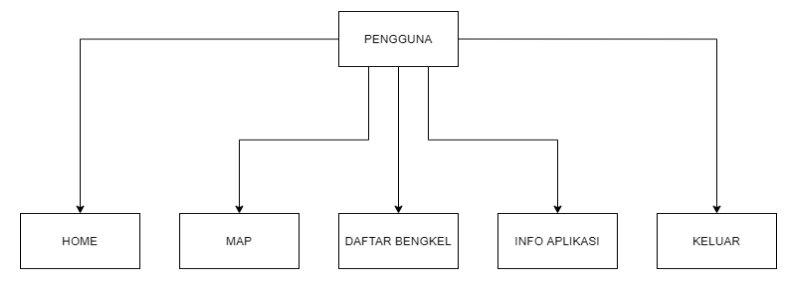

Gambar 3 Struktur menu aplikasi
Dari gambar 3 diatas, pada sturtur menu aplikasi pencarian bengkel di kota tebing tinggi tersedia 3 menu, yaitu :

1. Home

Home bertujuan untuk memberi informasi aplikasi

2. Мепи тар

Мепи map bertujuan untuk melihat lokasi pengguna smartphone berada

3. Мепи Daftar bengkel

Menu daftar bengkel bertujuan untuk memperlihatkan daftar bengkel yang berada ditebing tinggi

4. Мепи info aplikasi

Menu info aplikasi bertujuan untuk memberikan informasi profile pembuat dan profile aplikasi

\subsection{UseCase Diagram}

Berikut merupakan Use Case Diagram di aplikasi Pencarian Bengkel terdekat Pada Wilayah Kota Tebing Tinggi Berbasis Andorid

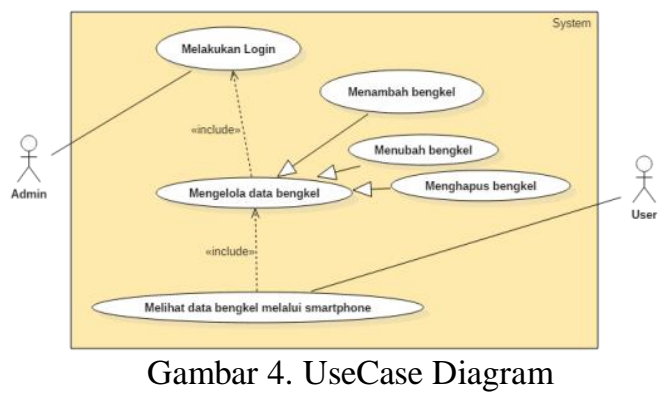

\section{HASIL DAN PENGUJIAN}

\subsection{Tampilan LoadingScreen}

LoadingScreen atau halaman loading yaitu halaman pertama yang pertama kali dijalankan Ketika aplikasi baru dijalankan atau dibuka. Aplikasi ini berisikan tentang nama aplikasi, logo aplikasi dan juga progress bar. SplashScreen digunakan untuk mempercantik aplikasi, Splash screen ini berjalan selama 2 detik kemdian akan melanjutkan kehalaman selanjutnya. Seperti gambar 4.

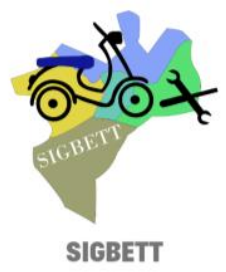

Gambar 5. Splash Screen Aplikasi

\subsection{Tampilan Home}

Tampilan home akan otomatis tampil Ketika spashscreen berakhir, tampilan home ini juga bisa diakses dari menu yang berada di menu item. Pada tampilan home ini berisikan logo aplikasi, nama aplikasi dan juga penjelasan singkat aplikasi. Halaman ini juga terdapat icon garis tiga yang berada 
di sebelah kiri atas, tombol ini berfungsi untuk membuka halaman menu item yang berada di aplikasi. Seperti gambar 5.

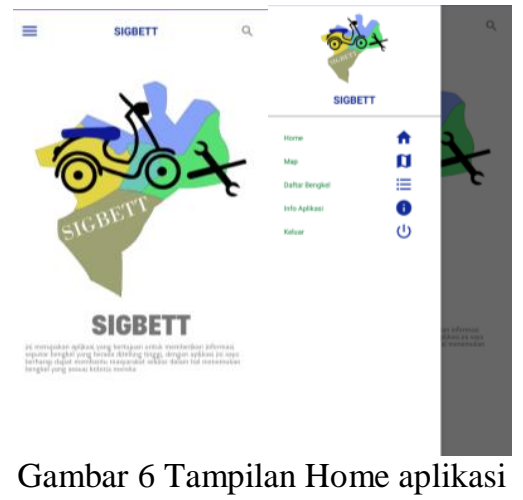

\subsection{Tampilan Map}

Pada halaman ini menampilkan peta beserta dengan tanda yang sudah ditandai bahwa ada bengkel, tanda tersebut bisa di tekan dan ditekan akan dilempar ke halaman berikut. halaman ini dilengkapi dengan tombol menampilkan lokasi kita, tombol search dan tombol cari berngkel. Seperti gambar 6

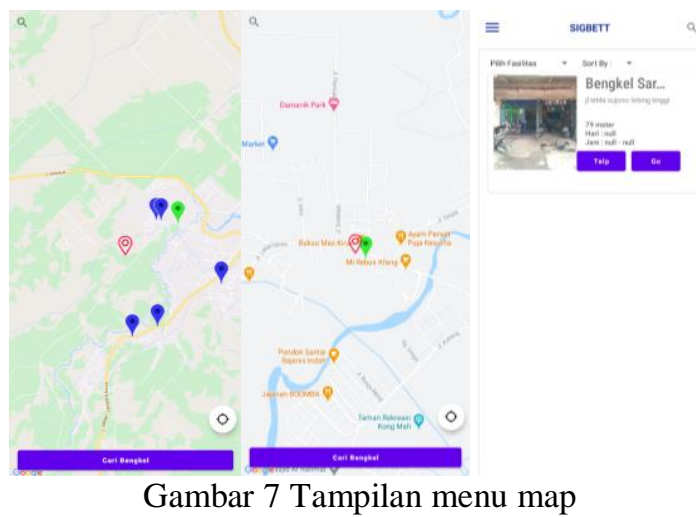

\subsection{Tampilan daftar bengkel}

Halaman ini menampilkan seluruh data bengkel yang berada di database, ditampilkan dalam card didalam card terdapat beberapa informasi yaitu nama bengkel, alamat bengkel, jarak bengkel hari buka, jam buka. Didalam card juga terdapat 2 tombol yaitu tombol go dan telp, jika tombol telp ditekan maka akan dilempar ke telepon kontak dan otomatis mengisi nomor pemilik bengkel, jika go ditekan maka akan dibawa ke aplikasi google maps dan menunjukkan rute terdekat ke tujuan. jika salah satu card ditekan maka akan dilempar ke halaman detail bengkel dengan menampilkan informasi bengkel yang dipilih, informasi yang ditampilkan berupa gambar sampul, nama bengkel, hari kerja, jam kerja, jarak, alamat, fasilitas bengkel dan juga gambar pendukung bengkel, halaman ini juga menampilkan tombol go dan telpon dimana fungsinya sama seperti halnya diatas. pada halaman ini juga terdapat dua buah dropdown yang pertama merupakan fasilitas dimana jika dipilih maka data yang tampil dihalaman ini hanya data yang memiliki fasilitas tertentu dan yang kedua sort by, ini berfungsi untuk mengurutkan data berdasarkan jarak dan nama. Halaman ini juga tersedia fitur searching dimana user dapat mencari data berdasarkan nama atau kecamatan atau kelurahan. Seperti gmbar 7

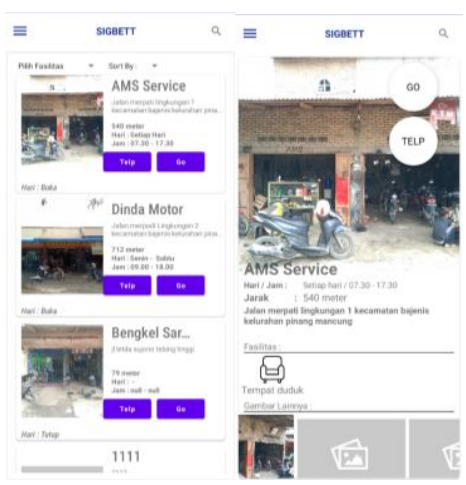

Gambar 8 Tampilan daftar bengkel aplikasi

\subsection{Tampilan info aplikasi}

Halaman ini menamilkan informasi kontak peneliti dan tujuan peneliti dalam membuat aplikasi ini, dihalaman ini juga terdapat logo beserta nama institusi tempat dimana peneliti bersekola. Seperti gambar 8

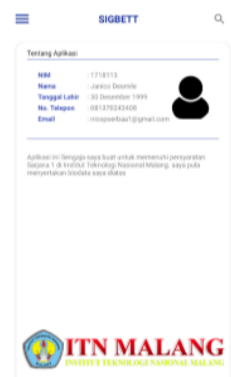

Gambar 9 Tampilan Info aplikasi

\subsection{Pengujian}

Scenario pengujian sistem meliputi pengujian fungsional sistem, pengujian metode Location Based Services dan pengujian formula haversine

1. Pengujian fungsional sistem

Pengujian fungsional sistem, dilakukan untuk mengetahui apakah aplikasi dapat berjalan baik pada sistem operasi android. Pengujian dilakukan pada 4 sistem operasi android yaitu android Nouget, Oreo, Pie, dan 10. Hasil pengujian fungsi sistem dapat dilihat pada tabel 1 di bawah ini

2. Pengujian metode Location Based Services Pada pengujian location based services peneliti menggunakan Google Maps Api untuk menerapkan fitur lokasi pencarian bengkel. Pengujian ini dilakukan menggunakan handphone peneliti yaitu Realme 5 bertujuan untuk mengetahui fitur-fitur apa yang berjalan dengan baik, berjalan jika memiliki syarat tertentu dan yang tidak berjalan. Tabel 2 
menunjukkan hasil pengujian metode pelayanan berbasis lokasi.

3. Pengujian formula haversine

Pengujian formula haversine dilakukan untuk mengetahui keakuratan dari perhitungan jarak menggunaka formula haversine. Pengujian ini dilakukan dengan cara membandingkan hasil jarak yang didapatkan dan mengecek jarak yang didapat dari aplikasi google maps. Tabel 3 menunjukkan hasil Pengujian formula Haversine

4. Pengujian User

Pengujian untuk menentukan apakah aplikasi yang dibuat memenuhi tujuan yang dibutuhkan oleh pengguna. Pengujian dilakukan secara online melalui kuisioner google form yang diberikan kepada responden yang merupakan masyarakat Kota Tebing Tinggi dengan memberikan link untuk mencoba aplikasi beserta dengan link video demo aplikasi yang disebar di youtube.

Tabel 1 Pengujian Fungsional Sistem

\begin{tabular}{|l|l|l|l|l|}
\hline \multirow{2}{*}{ Fungsi } & \multicolumn{5}{c|}{ Versi Android } \\
\cline { 2 - 6 } & $\mathbf{7 . 1}$ & $\mathbf{8 . 1}$ & $\mathbf{9 . 0}$ & $\mathbf{1 0 . 0}$ \\
\hline $\begin{array}{l}\text { Menampilkan lokasi } \\
\text { pengguna saat ini. }\end{array}$ & $\checkmark$ & $\checkmark$ & $\checkmark$ & $\checkmark$ \\
\hline $\begin{array}{l}\text { Menampilkan petunjuk Arah } \\
\text { antara User dan Pengguna }\end{array}$ & $\odot$ & $\odot$ & $\odot$ & $\odot$ \\
\hline Menampilkan lokasi Bengkel & $\checkmark$ & $\checkmark$ & $\checkmark$ & $\checkmark$ \\
\hline $\begin{array}{l}\text { Menampilkan daftar Bengkel } \\
\text { dikota tebing tinggi }\end{array}$ & $\checkmark$ & $\checkmark$ & $\checkmark$ & $\checkmark$ \\
\hline $\begin{array}{l}\text { Menampilkan data } \\
\text { berdasarkan Fasilitas }\end{array}$ & $\checkmark$ & $\checkmark$ & $\checkmark$ & $\checkmark$ \\
\hline $\begin{array}{l}\text { Mengurutkan data bengkel } \\
\text { berdasarkan nama }\end{array}$ & $\checkmark$ & $\checkmark$ & $\checkmark$ & $\checkmark$ \\
\hline $\begin{array}{l}\text { Mengurutkan data bengkel } \\
\text { berdasarkan jarak }\end{array}$ & $\checkmark$ & $\checkmark$ & $\checkmark$ & $\checkmark$ \\
\hline
\end{tabular}

Dimana : $\checkmark$ = Dapat dijalankan

$$
\text { (?) = Berjalan dengan ketentuan }
$$

$\mathrm{X}$ = Tidak dapat dijalankan

Dari Pengujian Operating System Android, fungsi dapat berjalan dengan baik di android Nouget, Oreo, Pie, 10 kecuali untuk fitur petunjuk arah antara pengguna dengan lokasi bengkel. Hal ini disebabkan keterbatasan API yang disediakan sehingga pengguna harus memiliki aplikasi Google Map untuk memakai fitur ini.

Tabel 2 Pengujian Location Based Services

\begin{tabular}{|l|l|}
\hline $\begin{array}{l}\text { Fitur Location Based } \\
\text { Services }\end{array}$ & Fungsional \\
\hline Lokasi pengguna saat ini & Berjalan dengan baik \\
\hline $\begin{array}{l}\text { Arah tujuan dari pengguna } \\
\text { ke lokasi bengkel }\end{array}$ & $\begin{array}{l}\text { Berjalan jika } \\
\text { memiliki aplikasi } \\
\text { bawaan google maps }\end{array}$ \\
\hline $\begin{array}{l}\text { Menampilkan lokasi } \\
\text { Bengkel }\end{array}$ & Berjalan dengan baik \\
\hline
\end{tabular}

Pada pengujian location based services peneliti menggunakan Google Maps Api untuk menerapkan fitur lokasi pencarian bengkel. Terdapat keterbatasan penggunaan pada Google Maps Api dikarenakan pengubahan kebijakan yang dilakukan oleh google.

Tabel 3 Pengujian Formula Haversine

\begin{tabular}{|c|c|c|c|c|c|}
\hline Uji & LU & $\begin{array}{c}\text { Daftar } \\
\text { bengkel }\end{array}$ & FM & GMA & $\begin{array}{c}\text { Selisi } \\
\mathrm{h}\end{array}$ \\
\hline \multirow{8}{*}{1} & \multirow{8}{*}{$\begin{array}{l}\text { Bulian } \\
\text { brohol }\end{array}$} & AMS Service & 1,47 & 1,6 & 0,13 \\
\hline & & Dinda Motor & 1,65 & 1,8 & 0.15 \\
\hline & & $\begin{array}{l}\text { Bengkel } \\
\text { Saragih }\end{array}$ & 0,88 & 1.0 & 0,11 \\
\hline & & Rizky Service & 5.0 & 5,5 & 0,5 \\
\hline & & $\begin{array}{l}\text { Terisma } \\
\text { Service }\end{array}$ & 4,6 & 5,7 & 1,1 \\
\hline & & Amin Service & 4,6 & 5.7 & 1,1 \\
\hline & & $\begin{array}{c}\text { Bengkel } \\
\text { Mitra } \\
\end{array}$ & 3,87 & 4,8 & 0,87 \\
\hline & & $\begin{array}{c}\text { Laban } \\
\text { bintang }\end{array}$ & 2,3 & 2,4 & 0,1 \\
\hline \multirow{8}{*}{2} & \multirow{8}{*}{$\begin{array}{c}\text { Lapang } \\
\text { an } \\
\text { brimob }\end{array}$} & AMS Service & 2,83 & 3,0 & 0,17 \\
\hline & & Dinda Motor & 2,97 & 3,2 & 0.23 \\
\hline & & $\begin{array}{l}\text { Bengkel } \\
\text { Saragih }\end{array}$ & 2,31 & 2,4 & 0,9 \\
\hline & & Rizky Service & 4,02 & 4,3 & 0,28 \\
\hline & & $\begin{array}{l}\text { Terisma } \\
\text { Service }\end{array}$ & 4,01 & 4,3 & 0.2 \\
\hline & & Amin Service & 4,01 & 4,3 & 0.2 \\
\hline & & $\begin{array}{c}\text { Bengkel } \\
\text { Mitra }\end{array}$ & 3,12 & 3,3 & 0,18 \\
\hline & & $\begin{array}{c}\text { Laban } \\
\text { bintang }\end{array}$ & 0,55 & 0,75 & 0,2 \\
\hline \multirow{8}{*}{3} & \multirow{8}{*}{$\begin{array}{l}\text { Simpan } \\
\mathrm{g} \text { beo }\end{array}$} & AMS Service & 4,65 & 5,4 & 0,75 \\
\hline & & Dinda Motor & 4,81 & 6,1 & 1,29 \\
\hline & & $\begin{array}{l}\text { Bengkel } \\
\text { Saragih }\end{array}$ & 4,16 & 5,8 & 1,6 \\
\hline & & Rizky Service & 7,83 & 8,1 & 0,27 \\
\hline & & $\begin{array}{l}\text { Terisma } \\
\text { Service }\end{array}$ & 7,81 & 8,7 & 0,89 \\
\hline & & Amin Service & 7,81 & 8,7 & 0,89 \\
\hline & & $\begin{array}{c}\text { Bengkel } \\
\text { Mitra }\end{array}$ & 6,99 & 7,7 & 0,71 \\
\hline & & $\begin{array}{c}\text { Laban } \\
\text { bintang }\end{array}$ & 4,49 & 5,4 & 0,91 \\
\hline \multirow{8}{*}{4} & \multirow{8}{*}{ kabicar } & AMS Service & 2,70 & 3,2 & 0,5 \\
\hline & & Dinda Motor & 2,86 & 3,4 & 0,54 \\
\hline & & $\begin{array}{l}\text { Bengkel } \\
\text { Saragih }\end{array}$ & 2,13 & 2,6 & 0,47 \\
\hline & & Rizky Service & 4,53 & 5.0 & 0,47 \\
\hline & & $\begin{array}{l}\text { Terisma } \\
\text { Service }\end{array}$ & 4,51 & 5,0 & 0,47 \\
\hline & & Amin Service & 4.51 & 5,0 & 0,49 \\
\hline & & $\begin{array}{c}\text { Bengkel } \\
\text { Mitra }\end{array}$ & 3,65 & 4,1 & 0,45 \\
\hline & & $\begin{array}{c}\text { Laban } \\
\text { bintang }\end{array}$ & 1,15 & 1,5 & 0,35 \\
\hline \multirow{5}{*}{5} & \multirow{5}{*}{$\begin{array}{c}\text { Kampu } \\
\text { ng } \\
\text { keling }\end{array}$} & AMS Service & 4,68 & 6,5 & 1,82 \\
\hline & & Dinda Motor & 4,84 & 6,6 & 1,76 \\
\hline & & $\begin{array}{l}\text { Bengkel } \\
\text { Saragih }\end{array}$ & 4,15 & 5,9 & 1,75 \\
\hline & & Rizky Service & 7,59 & 8,4 & 0,81 \\
\hline & & $\begin{array}{l}\text { Terisma } \\
\text { Service }\end{array}$ & 7.58 & 8,4 & 0,82 \\
\hline
\end{tabular}




\begin{tabular}{|c|c|c|c|c|c|}
\hline Uji & LU & $\begin{array}{c}\text { Daftar } \\
\text { bengkel }\end{array}$ & FM & GMA & $\begin{array}{c}\text { Selisi } \\
\mathrm{h}\end{array}$ \\
\hline \multirow{4}{*}{} & & Amin Service & 7.58 & 8,4 & 0,82 \\
\cline { 3 - 5 } & $\begin{array}{c}\text { Bengkel } \\
\text { Mitra }\end{array}$ & 6,73 & 7,4 & 0,67 \\
\hline & $\begin{array}{c}\text { Laban } \\
\text { bintang }\end{array}$ & 4,16 & 4,5 & 0,34 \\
\hline \multirow{4}{*}{6} & $\begin{array}{c}\text { AMS Service } \\
\text { Payaka } \\
\text { par }\end{array}$ & 0,54 & 0,55 & 0,01 \\
\cline { 3 - 6 } & Dinda Motor & 0,71 & 0,75 & 0,04 \\
\cline { 3 - 6 } & $\begin{array}{c}\text { Bengkel } \\
\text { Saragih }\end{array}$ & 0,08 & 0,08 & 0 \\
\cline { 3 - 6 } & Rizky Service & 4,28 & 6,0 & 1,72 \\
\cline { 3 - 6 } & $\begin{array}{c}\text { Terisma } \\
\text { Service }\end{array}$ & 4,27 & 6,0 & 1,73 \\
\cline { 3 - 6 } & Amin Service & 4,27 & 6,0 & 1,73 \\
\hline & $\begin{array}{c}\text { Bengkel } \\
\text { Mitra }\end{array}$ & 3,71 & 5,1 & 1,39 \\
\cline { 3 - 6 } & $\begin{array}{c}\text { Laban } \\
\text { bintang }\end{array}$ & 2,66 & 3,3 & 0,64 \\
\hline
\end{tabular}

Dimana : $\quad \mathrm{FM}=$ Jarak Haversine $(\mathrm{KM})$

GMA = Jarak google Api $(\mathrm{Km}$

$\mathrm{LU}=$ Lokasi User

Dari pengujian formula haversine dari lokasi pengguna yang berbeda, hasilnya dapat dilihat pada Tabel 2. Aplikasi pencarian bengkel cukup baik dalam menentukan jarak terdekat berdasarkan perbandingan jarak yang diberikan Google Maps Api dengan hasil perhitungan formula Haversine.

Tabel 4 Pengujian User

\begin{tabular}{|c|c|c|c|c|c|}
\hline \multirow{2}{*}{ No } & \multirow{2}{*}{ Pernyataan } & \multicolumn{4}{|c|}{ Respon } \\
\hline & & SS & $\mathbf{S}$ & TS & STS \\
\hline 1 & $\begin{array}{l}\text { Aplikasi sigbett mudah } \\
\text { digunakan }\end{array}$ & 5 & 5 & 0 & 0 \\
\hline 2 & $\begin{array}{l}\text { Tampilan Antar muka } \\
\text { dari aplikasi sigbett ini } \\
\text { terlihat menarik }\end{array}$ & 2 & 7 & 1 & 0 \\
\hline 3 & $\begin{array}{l}\text { Aplikasi sigbett ini dapat } \\
\text { membantu dalam } \\
\text { memilih bengkel yang } \\
\text { sesuai kriteria }\end{array}$ & 4 & 5 & 1 & 0 \\
\hline 4 & $\begin{array}{l}\text { Data bengkel di dalam } \\
\text { aplikasi sigbet ini } \\
\text { terbilang lengkap }\end{array}$ & 0 & 3 & 5 & 2 \\
\hline 5 & $\begin{array}{l}\text { Informasi bengkel yang } \\
\text { didalam aplikasi sigbett } \\
\text { akurat }\end{array}$ & 3 & 4 & 3 & 0 \\
\hline 6 & $\begin{array}{l}\text { Hasil jarak lokasi user ke } \\
\text { lokasi bengkel akurat }\end{array}$ & 3 & 6 & 1 & 0 \\
\hline & Total & 17 & 30 & 11 & 2 \\
\hline & Persentase & 28,3 & 50 & 18,3 & 3,4 \\
\hline & $\begin{aligned} \text { na }: \text { SS } & =\text { Sangat Set } \\
\text { S } & =\text { Setuju } \\
\text { TS } & =\text { Tidak Setu } \\
\text { STS } & =\text { Sangat Tic }\end{aligned}$ & & & & \\
\hline
\end{tabular}

Pada tabel 4 diatas dapat dilihat bahwa jawaban dari para responden menyatakan sebesar 17 respon sangat setuju, 30 setuju, 11 tidak setuju dan 2 sangat tidak setuju. Hal ini dapat dikatakan bahwa mayoritas responden menilai aplikasi yang dibuat sudah sesuai dengan apa yang mereka harapkan

\section{KESIMPULAN DAN SARAN}

\subsection{Kesimpulan}

berikut.

Kesimpulan dari penelitian ini adalah sebagai

1. Setelah melakukan pengujian Formula Haversine di 6 lokasi berbeda disimpulkan bahwa formula Haversine cocok dalam hal menentukan jarak dari dua titik point ditunjukkan dari selisih perbandingan jarak Haversine dengan jarak digooglemap tidak terlalu jauh pada pengujian perbandingan Haversine

2. Pengujian pada perangkat android Nougat, Oreo, Pie, 10 menunjukkan bahwa semua fitur yang dirancang dapat berjalan dengan baik.

3. Penerapan Formula Haversine mampu memberikan informasi jarak dari lokasi pengguna ke lokasi bengkel dalam satuan meter dan kilometer

4. Pengujian user menunjukkan bahwa mayoritas responden menilai aplikasi yang dibuat sudah sesuai dengan apa yang mereka harapkan.

\subsection{Saran}

Saran yang diberikan berdasarkan penelitian ini adalah sebagai berikut.

1. Penelitian selanjutnya dapat dilaksanakan dengan menggunakan Location Based Services yang open source, yaitu Mapbox, Mapfit.

2. Untuk penelitian selanjutnya bisa menggunakan Euclidean distance dalam mencari jarak lokasi user ke lokasi tujuan

\section{DAFTAR PUSTAKA}

[1] Abdul Haris Rosyidi, 2005, Analisis Kesalahan Siswa Kelas II MTs Alkhoiriyah dalam Menyelesaikan Soal Cerita yang Terkait dengan Sistem Persamaan Linear Dua Peubah, Tesis Tidak Dipublikasikan, Surabaya.

[2] Yoga, A. J. 2013. Perancangan Sistem Inventory Sparepart Motor pada CV. Surya Jaya Jepara.

[3] Nopriyanus V. Y. R. B (2010). Aplikasi Pencarian Tempat Wisata Menggunakan Metode Location Based Service Pada Wilayah Kabupaten Timor Tengah Selatan Berbasis Android. Jurnal Mahasiswa Teknik Informatika Vol, 4(1).

[4] Deti marlena, Hari Aspriyono, 2019. Sistem Informasi Geografis Letak Lokasi Rumah Sakit Dan Apotek Kota Bengkulu Berbasis Android. Jurnal Media Infotama, Vol. 10 No. 2, September 2014

[5] Ichwan Fachruddin Budiarto, 2019. Sistem Informasi Geografis Sebaran Pondok Pesantren Di Kota Malang. Jurnal Mahasiswa Teknik Informatika, Vol. 3 No. 3, Maret 2019

[6] Hirarki Ardi Pratama W (2020). Penerapan Location Based Service Untuk Pencarian Lokasi Rapat Menggunakan Metode Design Sprint. Jurnal Mahasiswa Teknik Informatika Vol, 4(1).

[7] Yulianto, Ramadiani, Awang H K. 2018. Penerapan Formula Haversine Pada Sistem 
Informasi Geografis Pencarian Jarak Terdekat Lokasi Lapangan Futsat. Informatika Mulawarman: Jurnal Ilmiah Ilmu Komputer, 13(1)

[8] Erviana Devie, Edi Winarno (2018). Aplikasi Location Based Service Untuk Informasi Kuliner Di Yogyakarta. Jurnal DINAMIK Vol, 23(1) 